\title{
Unveiling the shadows of meaning: Meaning-making for perpetrators of homicide
}

Martha Ferrito, Adrian Needs, Gwen Adshead

\begin{abstract}
Human beings are thought to have unique capacities to interpret and make meaning after major life events. However this process may be complicated and difficult after events that involve anger and aggression and when dangerousness and destructiveness come to the fore. Meaning making may be especially challenging when such an event is incomprehensible to the victim's family and society, due to the perpetrator's irreversible actions and the painful awareness that a human life has been lost. Meaning-making for the perpetrator, including owning of responsibility, in the aftermath of a serious and violent crime remains under-explored; perhaps this is because violent death is an extraordinary behavior with tragic consequences on the victim that invokes enormous anxiety at the thought of exploration. The aim of this paper is to draw upon criminological, forensic and psychology literature to provide a unified perspective on meaning-making processes and what meanings are made for and by the offender in the aftermath of homicide. From the perspective of the perpetrator, challenges might include how sense can be made of the tragedy, including how a redemptive story can emerge and in turn lead to pro-social identity changes. The paper concludes by highlighting consequences and lack of adjustment following incomprehensibility.
\end{abstract}

\section{Introduction}

Human beings have evolved to have expanded neocortical function which allows them to reflect and make meaning of environmental stressors, including events that threaten or change the way they live their lives or relate to others. Meaning-making is a fundamental aspect of the human condition and as Baird (1985) noted, creating meaning is distinctive to being human. Yalom (1980) observed that "the human being seems to require meaning...[as] to live without meaning, goals, values, or ideals seems to provoke considerable distress" (p.422). It has been recognised increasingly that such aspects (and related facets such as agency) must be understood in a context of social interaction and social embeddedness that demonstrates that 'mind' does indeed extend beyond the individual (De Jaegher and Froese, 2009 ; Varela, 1979). This has important implications for understanding the situation of homicide perpetrators and how issues such as reconciliation may lead to renewed development.

Meaning-making is a challenge to define, and there are a variety of definitions (Klinger, 1998) with a lack of standardized terminology (Park, 2010). It has been conceptualized as a process and an outcome (Park, 2010), entailing "[the] coming to see or understand [a] situation in a different way and reviewing and reforming one's beliefs and goals in order to regain consistency" (Park \& Ai, 2006, p. 393). In recent decades, the study of meaning-making has been explored extensively in relation to events that involve 
coping with trauma, loss, and grief (Armour, 2003; Currier et al., 2006; Edmonds and Hooker, 1992; Gillies and Neimeyer, 2006; Janoff-Bulman and McPherson, 1997; Neimeyer, 2001; Park, 2010; Park and Folkman, 1997). McAdams (2001a) argued that storytelling and narratives create meaning and continuity in our life after traumatic or negative events, a process that has been harnessed in therapy (e.g. Meichenbaum, 2006). We construct our sense of identity, meaning and purpose by creating and editing events in terms of a narrative that encompasses both experience and choices. However, when we experience a traumatic event, our propensity for meaning-making is challenged, as our basic assumptions about the self and the world are shattered (Burnell et al., 2011; Janoff-Bulman, 1992; Joseph and Linley, 2005).

To date, there has been little formal study of meaning-making processes for those who inflict catastrophes on others, who commit offences that cause trauma, grief and loss; this includes those who may experience trauma and bereavement due to the loss they have caused. Yet, those who work in the rehabilitation of offenders acknowledge that perpetrators of serious violence often experience changes in self-identity, values, and how they connect with others (Drennan and Alred, 2011; Giordano et al., 2002; Laub and Sampson, 2003; Maruna, 2001; Sampson and Laub, 1993; Stevens, 2012). There is some evidence that accomplishing meaning-making is associated with positive outcomes for perpetrators of interpersonal violence (Gilbert, 2006; Maruna, 2001; McAdams et al., 1997; Wright et al., 2007).

It could also be argued that constructing meaning-making following criminal offending is at the heart of desistance from offending. For example, Maruna (2001) argued that understanding their offending in terms of a meaningful pattern can offer perpetrators a way to reflect on meaning and change actions in the future. Thus a perpetrator might seek a way out of an encircling sense of shame and guilt by helping others; this then provides an alternative source of meaning and helps to maintain prosocial actions in the future. Clark and Crossland (1985) developed Harré's (1975) argument that suggested how one comes to act is dependent on unlocking behavioral capacities that come to fruition under certain conditions. It is apparent that offenders have a range of values and goals that ultimately can direct them to living a fulfilling life (Maruna \& LeBel, 2003), whilst identifying the conditions that enable prosocial action and the procedural knowledge with which it is achieved can give rise to understanding of how this new direction is made meaningful by the perpetrator. Similar processes might of course be implicated in offending behavior, for example a well-established pattern of drinking to excess can have a bi-directional relationship to negative affective states, especially when there are deficits in self-regulation (Day, Howells, Heseltine, \& Casey, 2003). Accompanied by contextual details and reminiscences, it is likely to be reflected and elaborated as part of the narrative of an individual's life (Needs \& Neale, 2016). The narratives of offenders can provide important insights into the nature, dynamics and genesis of violent offending (Presser, 2009; Youngs and Canter, 2013). 
Maruna's (2001) work with offenders who desist from crime indicates that those who can make meaning of their criminal life choices as part of a story of ultimate transformation and redemption are more likely to desist from crime than those who cannot. Heintzelman and King (2013) observed that definitions of the construct of meaning typically refer to three aspects: purpose (goal direction), significance (mattering) and coherence (the presence of reliable connections). It could therefore be suggested that the process of constructing meaning has the potential to lead offenders to face their future with openness and renewed hope (Ferrito, Vetere, Adshead, \& Moore, 2012), more likely to access opportunities for growth and 'making good' (Maruna, 2001).

Although there is little formal study of the experience of homicide perpetrators, data on the nature and circumstances of individual cases collated from perpetrators who committed homicide (e.g. Cullen and Newell, 1999; Sparks, 1999; Ferrito et al., 2012 ; Parker, 1995), demonstrate that there is growing trend in favor of exploring meaning-making in offenders. This is a group of people who are of real interest, given the concerns about what they have done and what they might do in future. Homicide perpetrators are likely to serve longer in prison than other violent offenders, are under license and scrutiny for years after release and are at high risk of suicide compared to the general population (Lindqvist, Leifman, \& Eriksson, 2007). Their lives are irrevocably changed after an event that changes their identity for ever, an event that professionals call the 'index offence' (i.e. the offence that literally 'points to' and marks them out). The index offence not only leads to a series of legal and criminal justice consequences such as detention, but also to profound social, emotional and psychological repercussions. The 'facts' as portrayed by the media and the subsequent meaning the public create are also aspects that impact on the process of meaningmaking for the perpetrator.

Understanding both the index offence and mental aftermath demands serious psychological investigation, including the process of meaning-making. The perpetrator's narrative often functions as a way of organizing their history in relation to their index offence and in the present, and can indicate acceptance or refusal of responsibility and guilt. The journey towards the creation of meaning, which includes sense-making, benefit finding and identity change (Neimeyer, 2006ab) is an intensive process and inherently a personal endeavor that must also sit within social experience as the process of meaning-making unfolds in the social structures in which it is embedded.

The present paper aims to uncover how offenders come to terms with having committed homicide, focusing on meaning reconstruction processes and the resultant meanings attained. Theoretical perspectives will be used to discuss how offenders who committed homicide cope with and come to terms with this experience, as well as the consequences for their well-being and adjustment when they are unable to make sense of these experiences. 


\section{Life after homicide: offending as trauma}

Common initial psychological responses to having seriously offended include periods of disbelief, detachment and numbness (Brunning, 1982; Horne, 1999). This detachment can develop into denial or it can set in motion the subsequent stage of partial acceptance (Horne, 1999). Coming to terms with the reality of the offence requires 'full acceptance', where the person fully acknowledges and develops a sense of agency and responsibility. Cox (1974) describes the process of taking responsibility retrospectively, and how this is intimately linked with the development of insight and the capacity to sustain emotional disclosure.

Several studies have found that homicide perpetrators may be traumatized by the homicide event itself and suffer from a range of post-traumatic psychopathology (Adshead, 2003; Papanastassiou et al., 2004; Adshead et al., 2015; Harry and Resnick, 1986; Rynearson, 1984; Thomas et al., 1994). Suicide rates are known to be high, both immediately after arrest and persistently throughout trial and detention. Perpetrators of homicide can feel stuck, and develop psychiatric difficulties, including post- traumatic stress disorder (PTSD), complicated grief, and clinical depression in response to their offences (Adshead et al., 2008; Papanastassiou et al., 2004; Pollock, 1999). They can also experience particularly high levels of guilt (Papanastassiou et al., 2004), avoidance (Curle, 1989; Pham and Willocq, 2013), decreased concentration, and increased agitation (Curle, 1989), with the experience of shame being closely linked to the development of traumatic symptoms (see Taylor, 2015). Homicide offenders are also found to be highly susceptible to the development of acute stress disorder (ASD) which is characterized by severe anxiety, dissociative states, and reduced emotional responsiveness (Pham \& Willocq, 2013). It differs from PTSD in that it is usually a more immediate, short-term response to the trauma that lasts between two days and four weeks, and if ASD symptoms persist for more than a month, then a PTSD diagnosis is usually considered (Bryant \& Harvey, 2000).

Extensive evidence highlights that violent offenders have often experienced a history of trauma and childhood abuse (Coid, 1992; Heads et al., 1997; Ferrito et al., 2012; Maruna, 2001; McFarlane and Yehuda, 1996; Perry, 1999; Presser, 2008; Van der Kolk et al., 1996). These findings are important when considering that the Diagnostic Statistical Manual-IV (DSM-IV) field trials have indicated that childhood interpersonal trauma is a strong predictor for developing chronic or complex PTSD and DES or DESNOS (disorder of extreme stress not otherwise specified: American Psychiatric Association, APA, 2013). Although there is a considerable overlap with the formal diagnosis of PTSD, complex PTSD highlights additional issues, such as interpersonal impairment and self-destructive behaviors (APA, 2013). There is a recognized body of literature that documents the relationship between child abuse/early trauma and subsequent aggressive and criminal acts (Widom and Maxfield, 2001; Smith et al., 2005; Skowyra and Cocozza, 2007). The continuing role of past traumatic experiences on the lives of perpetrators may be further marked by reenactment of trauma through behaviors such as self-harm, depression or suicide and/or harming others 
and involvement in criminal activity (Yoder, 2005), which is also described using the term of 'compulsion to the trauma' (Van der Kolk, 2007; Van der Kolk et al., 2007). The trajectory of subsequent outcomes in terms of meaning-making is affected by a range of influences, and the nature and continuity of the difficulties in processing will most of the time need psychological treatment to unpack the trauma that overshadowed the potential for meaning-making.

Those who experience trauma may be offered psychological therapy to help them manage symptoms and to recover or improve their mental health. Confronting and attempting to understand trauma is often a journey that starts in psychotherapy. Once a core activity of many psychologists in prisons, in recent years it is often the case that little has been offered to homicide perpetrators beyond standardised programmes aimed at building skills and changing attitudes; even analysis of index offences in risk assessment or to aid in identifying treatment needs can relatively cursory (West \& Greenall, 2011). Certainly there is, a paucity of empirical studies of therapeutic interventions specifically for people who have taken someone's life. However, Brunning (1982) described running a group in prison for homicide perpetrators, Hillbrand and Young (2008) and Adshead, Bose, and Helliwell (2012) report on therapy groups for people who have killed either a parent or a family member or partners. Adshead et al. (2015) also explain how they set up a group for men who had killed a stranger. In the group the process of meaning-making is supported through the group members telling their story; narrative re-telling with a focus on metaphorical language, and the use of reflective, attachment theory-based therapies, shifts the content of their narration from 'thin' to 'thicker' stories that include the context and other features required more fully to understand the violent behavior (Adshead, 2014; Adshead et al., 2015).

\section{Sense-making and meaning reconstruction in identity change}

After a violent offence, the processes of arrest, trial and detention change the offender's life fundamentally. The story that the offender constructs and reports will influence how the offender will live with people and how he/she will cope with the knowledge that he/she has killed. Meaning-making involves storytelling (McAdams, 2001a), and in order to understand oneself, people reconstruct their life story by using their narrative memory (McAdams, 1987; McAdams, 1990; McAdams, 2001b; Singer and Salovey, 1993). Their history is, therefore, conveyed through "language that is commensurate with meaning" (Polkinghorne, 1988, p.7) that becomes the vehicle of how the narrative is reported; this presents an example of the way in which actions can be understood through semantics (Anderson, 1997). Ultimately, the unfolding of the narrative structure within the story will centrally illuminate the individual's personality (McAdams, 1996). Evidence suggests that the index offence has meaning to the perpetrator and can be understood in the context of the perpetrator's internal world, developmental history and relationships (Ferrito et al., 2012; Maruna and Copes, 2005; Presser, 2008). 
Presser (2008) highlighted that perpetrators of violence often frame their lives in terms of a narrative of 'heroic struggle', whereby they had gone through some ordeal but redeemed their past to themselves and others. Similarly, Maruna (2001) who has studied how criminals reform and "go straight", has suggested that criminals who re-story their struggle with life can experience changes in meaning and new opportunities for growth and 'making good' can occur. The author describes how the offender's new story has to be "logical, believable and respectable" in order to justify the turnaround (p.86), whilst Rotenberg (1987) emphasized the need to have to return and re-establish the "old me" that is conceptualized by the ex-offender as a self that entails positive qualities. The analogy "find the diamond in the rough" used by one the participants interviewed by Maruna $(2001, \mathrm{p} 95)$ described how the offender had to disentangle the self ('the diamond') from the 'rough' (i.e. negative environmental influences). Some of the difficulties in achieving this in an environment where individuals can adopt a false persona in place of the pre- prison self are outlined by Schmid and Jones (1991).

In the clinical literature, Gillies and Neimeyer (2006) explicitly considered identity change in the context of grief as a form of meaning reconstruction. The idea of meaning reconstruction in relation to identity changes is less explicitly articulated in the criminological literature, although it has been suggested that offenders can move beyond the identity conferred on them by their manner of offending to redefine and rediscover themselves when they acknowledge responsibility for their role in negative past experiences (Adshead et al., 2015; Drennan and Alred, 2011; Vaughan, 2007). Similarly, Vaughan (2007) highlights that desistors fashion a "narrative identity" by engaging in a moral assessment of their past and dedicating themselves towards a better future by enhancing a sense of personal agency and self-reflection which directs them to what truly matters to them (p.390).

Related work concerns the dramatic impact of trauma on self-continuity and the unfolding sequence of identity (Zepinic, 2012). Self-discontinuity in this case is demarcated in terms of "the smooth flow of individual lives (which) can be interrupted, bent, and sometimes broken by the history in which they are embedded" (Broman, Hamilton, \& Hoffman, 2001, p. 4), leading to "self-discontinuity". This can be defined as a "sense of disjointedness between one's past and present self" (Sedikides, Wildschut, Routledge, \& Arndt, 2015, p. 2015). Perpetration of homicide in this case can also lead to another facet of self-continuity, the loss of a social identity. This can have negative implications in relation to mental health (Bonanno et al., 2001; Cruwys et al., 2014; Sani, 2008; Jetten et al., 2002). Specifically, discontinuity generates anxiety, negative mood and compounds ineffective coping (Zimbardo, 1999) whilst increasing the risk of alcohol misuse, violence and suicide (Chandler and Proulx, 2008; Sadeh and Karniol, 2012; Sedikides et al., 2015) and impairing future adjustment (Sadeh \& Karniol, 2012).

Another perspective is provided by research on 'possible selves' (Markus \& Nurius, 1986). The possible self or future self, defined "as the self, one would like to become or the self, one would not want to become or 
fear that one might become" is a working identity, subject to change and based on a balance towards benefits versus costs (Paternoster \& Bushway, 2009, p. 1113). Paternoster and Bushway (2009) argue that the offender's working identity will become less satisfying as he/she perceives future failures if he/she continues to abide by the criminal offender identity. Markus and Nurius' (1986) original formulation differentiated possible selves (PSs) which refer to what we want to become (hoped-for selves) and those that prompt movement away from undesired outcomes (feared selves). Hoyle and Sherrill (2006) highlight that PSs provides a "roadmap" which guides what one can do to both achieve the positive future self and avoid the negative possible self. Crucially, these changes to personal identity and self-narrative cohere with formulations of the process of desistance from crime (Giordano et al., 2002; Laub and Sampson, 2003; Maruna, 2001; Sampson and Laub, 1993; Stevens, 2012).

\section{Benefit finding: 'making good' and the redemptive narrative}

The consideration that there might be 'benefits' or growth for the perpetrator through their actions can be difficult to contemplate when there is a person that has died and families and other victims who are grieving. Research on meaning-making suggests that people may often demonstrate resilience, growth, and prosocial behaviors in response to extremely negative life events (Gilbert, 2006; Dunlop et al., 2015).

Furthermore, the clinical literature describes positive changes following trauma, loss and suffering (Duck, 1982; Harvey, 2008; Neimeyer, 2006b; Orbuch, 1992; Stroebe et al., 1993; Weiss, 1988; Wethington, 2003). Baumeister (1991) reported that when people experience negative or unexpected events, they tend to start searching for meaning. In this regard, the individual might realize what it is they want to do in the future because of dissatisfaction with crime and past life that is experienced as an accumulation of displeasure or what is known as "crystallization of discontent" (Baumeister, 1994).

One form of benefit-finding is the redemptive narrative (McAdams \& Bowman, 2001). Ferrito et al. (2012) observed that offender patients' personal strength enabled them to shift from focusing on a discouraging past to facing the future with openness and renewed hope. These findings are consistent with literature on positive psychology which emphasizes how people who become active agents can recreate and reshape themselves, their environment and their future (Seligman \& Csikszentmihalyi, 2000). Hence, reinterpreting circumstances and reconstructing meaning can reveal the importance and value of life (Janoff-Bulman, 1992; Taylor, 1989). Joseph, Linley, and Harris (2005) describe the positive changes that can follow from trauma and adversity such as increased spirituality, compassion and personal strength. In many ways, this idea also resembles what Mamali and Dunn (2011) call "crucial experiences" that describe the qualities of critical and decisive life experiences that challenge existing reality and have the potential to reveal new meanings (p.103).

Research with offenders who desist from crime suggests that desistors find meaning in a life that has been deemed a waste, by turning their experiences into a newfound redemptive narrative (Maruna, 2001). The 
argument is that for something to be redeemed, it has to be re-evaluated, and the suggestion is that this re-evaluation is a positive one (Radzik, 2009). Throughout history, there are examples of people who find solutions to problems in the most adverse conditions (Frankl, 1984). Emerging literature on desistance from offending is based largely on McAdams, 2001b; McAdams, 2006 ideas on transformation of identity after negative events. Maruna (1997) describes how men who desist from offending turn their negative experience (e.g. a family member dies) into a positive narrative (e.g., a person develops greater empathy for others). This positive narrative is subsequently described as the 'redemption' script (or recovery story), and refers to the social processes of this script as a way of making good. By contrast, a 'contamination' sequence encodes the opposite movement - from good to bad.

In secular language, redemption is often implied in such expressions such as: 'every cloud has a silver lining', 'time will heal all wounds', 'where there is a will there is a way' and 'putting the past behind'. All these metaphors, according to McAdams (2006) convey a move from a negative state or standing to a positive one. Making good implies a reconstruction of the self. Maruna and Ramsden (2004) describe five themes that underpin the redemption narrative process. The first theme is reparation and generativity that encompasses acts of "reciprocity, mutual obligation, restitution, making amends and carrying the message to others" (p.142). Generativity was defined by Erikson (1950) as the concern for, and commitment to promoting the next generation. Generativity is linked with desistance (Maruna, 1997; Maruna et al., 2004). The focus on generativity is about looking-forward to the future rather than dwelling on anger and guilt about the past, which functions as "a process of repentance" (Peteet, 1993, p. 265).

The second theme of redemptive narratives involves tragic optimism and providence. Tragic optimism (Frankl, 1984) has been conceptualized as the active capacity to hope in spite of tragic experience, or the belief that there is value to be gained by virtue of having experienced a trauma (Lerner, 1980), with the possibility of accessing agency in places where there is limited resource and options. Furthermore, in the redemption script, the past becomes a useful opportunity for a positive present and future (Maruna \& Ramsden, 2004). Other scholars such as Tedeschi and Calhoun (2004) pioneered the concept of 'posttraumatic growth' (PTG) that is defined as "the experience of positive change that occurs as a result of the struggle with highly challenging life crises" (p. 1). Emerging evidence has shown that PTG is associated with desired therapy outcomes among offenders (Guse and Hudson, 2014; Mapham and Hefferon, 2012; Van Ginneken, 2014). It has also been identified following psychological treatment for offenders (Mapham \& Hefferon, 2012), the initial entry shock of being imprisoned (Van Ginneken's, 2014) and during incarceration (Guse and Hudson, 2014; Elisha et al., 2013).

The third theme is acknowledgment of vulnerability and mutual dependency. This involves the individual recognizing imperfection and sharing this vulnerability whilst drawing strength from others (Maruna \& Ramsden, 2004). This theme has parallels to the growing body of literature that meaning can emerge when views and vulnerability are shared within a safe and supportive social context; this has been reflected in 
research with veterans (Brinn \& Auerbach, 2015); Alcoholic Anonymous (AA) (Brickman et al., 1982); and even in group therapy for homicide perpetrators (Adshead et al., 2015). In these social context's shared norms, goals and aspirations alleviate the sense of rejection and stigma experienced and also provide a source of shared perspective, and a space to evaluate the self (Cruwys et al., 2014 ; Jetten et al., 2014). Another theme is embeddedness, in which the person begins to feel as an equal member of the community, and finds inner peace and serenity. Also, the process of re-socialization is important for desistance, and as such is associated with shifts in values (Farrall \& Calverley, 2006). Uggen, Manza, and Behrens (2004) suggest that the self-concept of being a reforming citizen is the principal mechanism for interpreting role transitions and desistance from crime.

The final theme of coherence and internal integration is characterized by internal cohesion, personality integration and a sense of wholeness (Emmons and King, 1988; May, 1988). This theme focuses on the offenders' positive well-being and health rather than on pathogenesis and illness. Psychological trauma can pose particular challenges to enabling re-evaluation of one's life into a redemption narrative. Trauma can result in disturbances in a wide range of psychological processes including attention, cognitive-affective reactions, failure to make meaning of one's experience and beliefs, memory, coping strategies and social support. As a result, a number of information-processing analysis theories (emotional processing theory: Foa and Riggs, 1993; Foa and Rothbaum, 1998; dual representation theory: Brewin, 2001; Brewin et al., 1996; cognitive theory: Ehlers \& Clark, 2000) have been proposed that draw attention to the role of impaired or incomplete processing of the cognitive and emotional aspects of the trauma. These theories suggest that more complete processing is crucial for the integration of emotional and cognitive elements that have been disrupted and in order to reconcile experiences into coherent memories, to construct more adaptive meaning and to assimilate trauma into consciously accessible verbal memory (Brewin et al., 1996; Ehlers and Clark, 2000; Horowitz, 1986; Janoff-Bulman, 1992). However, it has been argued that assumptions about fragmented or incomplete processing of traumatic memories are based on methodologically flawed empirical findings (Rosen \& Lilienfeld, 2008), and vulnerability to development and maintenance of PTSD is dependent on social bonds (Charuvastra \& Cloitre, 2008). In this regard, meaning-making has a central role in understanding how people adjust to stress and trauma. Park (2010) suggested that the meaning we attribute to particular events might be different from that of our more general belief systems (in terms of predictability, safety or fairness); reconciliation is necessary to reduce the distress associated with this discrepancy and to bring a sense of order and coherence.

\section{Meaning in action: behavior change}

Emerging literature is highlighting the potential of providing opportunities for activities and experiences that create new pathways for developing meaning and identity. These include the 'Listener' scheme in which prisoner volunteers trained by the Samaritans offer face to face emotional support to their peers (Perrin \& Blagden, 2014). Perrin and Blagden (2014) also reported how the experience of being a listener 
enabled prisoners to experience profound changes in self-identity and gain meaning and purpose in their lives. Arguably, the meaning of the story and the function it serves for the speaker becomes central in providing unity and purpose to the prisoner's life. This, in turn, helps in the development of a 'healthy' and coherent life story and a positive direction in relation to autonomy and relationships with others, laden with hope and possibility. In addition to influencing identity (Singer, 2002) it also provides crucial experiences of using and consolidating a new role and associated perspective (Giordano et al., 2002).

On the other hand, questions might be raised concerning the extent to which previously held meanings and identities can be replaced or left behind. The idea that narrative influences criminal action (Canter, 1994; Canter and Youngs, 2012; Youngs and Canter, 2011; Youngs and Canter, 2012) can also be true in relation to an offender's narrative with regard to being an instigator of crime (Presser, 2009). Violence can be related to an offender's attempts at internal agency, whilst the emotional qualities of the event for the offender (Youngs and Canter, 2012 ; Katz, 1988), including moral emotions, can contribute to violent acts seen in terms of defending communal values and moral imperatives such as 'honor' (Katz, 1988). Also relevant to this process are violent offenders' implicit theories about violent acts (Ward, 2000) and enduring cognitive schemas about self and others (Beck et al., 2004) that reinforce normalization of violence (Polaschek, Calvert, \& Gannon, 2009) and consequently lead to lack of self-control (Gottfredson and Hirschi, 1990; Lynam et al., 2000; Moffitt, 1993; Wilson and Herrnstein, 1985). Arguably, this raises the issue whether narrative change is more or less difficult when the initial narrative, identity and associated schemas are strongly or weakly held (Stein \& Markus, 1996). Furthermore, identity can also perpetuate criminal behavior through labelling. Labelling theories (Goffman, 1963; Lemert, 1967; Schur, 1971) consider the impact of social audience in imposing a label that influences and creates the basis of one's identity. Although not all individuals labelled as criminal behave accordingly (Asencio \& Burke, 2011), one outcome of labelling may be that the imposition of a label renders the person less able to access opportunities to construct an ongoing and fruitful story (Presser, 2009).

\section{Factors conducive to meaning-making}

Changes in criminal behavior are significantly related to positive marital and parental attachment as well as job stability (Sampson and Laub, 1993; Sampson and Laub, 2003). Hence, stronger family ties and constructive connections to employment are linked to reduction in criminal behavior (Sampson \& Laub, 2005). Life-course studies also suggest that imprisonment may constitute a turning point in the incarcerated offender's criminal trajectory (Sampson \& Laub, 1993). When these areas of social control (through employment, marital and parental attachment) are reduced, offenders have a smaller incentive to abstain from reoffending (Graham and Bowling, 1995; Sampson and Laub, 1993). Indeed the role of negative life events, such as relationship breakdown, that are antecedents to many homicide offences has been largely neglected in the psychological and criminological literature (Needs, 2015). 
Baumeister and Leary (1995) argue that human beings have a "need to belong". This suggests that we function best when we have secure relationships characterized by loving concern and frequent interaction. Furthermore, relationships that promote a sense of belonging are especially likely to promote meaning (Lambert et al., 2013). Interpersonal relationships and social connectedness are an integral aspect of human psychological functioning. Consequently, the form and content of individual narratives can be seen as emerging from interactions between the self and relationships but also within the broader social-cultural influences within which the individual is embedded. Trauma itself can be seen as socially mediated (Charuvastra and Cloitre, 2008; Needs, 2016; Sharp et al., 2012). However, the process of re-socialization is not easy and exclusion might be imposed or elicited.

Related research on moral injury on war-related trauma suggests that possible dissonance between "fundamental assumptions about how things should work and how we should behave" Litz et al., 2009, p.699) and inability to integrate an event within existing self- and relational schemas can lead to reluctance to utilize social support, or an individual may in turn be rejected as a result of perceived moral violation. More generally, research on veterans supports the idea that symptoms of PTSD might reject or discourage social support (Sippel, Pietrzak, Charney, Mayes, \& Southwick, 2015) further contributing to a sociallydisturbed or limited processing following exposure to extreme, morally challenging experiences.

The arguably pivotal role of perceived social acceptance and acceptability (Needs, 2016) has been noted elsewhere. Williams, 2001; Williams, 2007 argued that ostracism threatens four fundamental needs: the need to belong, self-esteem, need for control, and meaningful existence. As a consequence this leads to a decrease of positive affect and an increase of negative affect (Cohen and Wills, 1985; Leary, 1990; Williams et al., 2000). Of particular relevance to offending, several laboratory studies found a causal connection between various forms of exclusion and aggressive behavior (e.g. Twenge et al., 2001; Twenge et al., 2007b; Twenge et al., 2007a ; Warburton et al., 2006). Hence, whilst social withdrawal and anger may make less accessible the social support which is important for the restoration of resilience in the context of trauma (King et al., 2006 ; Ozer et al., 2008), this may also make continued offending more likely.

Researchers such as Burnell et al., 2006; Burnell et al., 2010 have looked at veterans' narratives of meaningmaking and reconciliation. Specifically, they argued that social support is a vital factor in the reconciliation of traumatic memories (Burnell et al., 2010). They have used the term reconciliation in terms of how traumatic events can be integrated into the overall life story, increasing coherence and reducing the intensity and prevalence of traumatic memories (Burnell et al., 2006; Hunt, 2010). Research into processes of reconciliation and meaning-making in homicide perpetrators is largely absent. 


\section{Reconciliatory interventions in the criminological arena}

Definitions of reconciliation are typically linked to retributive justice, restorative justice, political and social justice perspectives. The dominant public discourse of reconciliation is associated with Truth and Reconciliation Commissions (TRCs) that promote social recovery through reconciliation, centred upon disclosure in a public forum, following societal conflict (Androff, 2010)..

Other literature on health and illness, has conceptualized reconciliation as development (Wiklund, 2008a; Wiklund, 2008b; Trenvåg and Kristoffersen, 2008; Pennebaker and Seagal, 1999) and as a transition to a new way of looking at life, from what it has been to what it is now (Gustafsson, Wiklund-Gustin, \& Lindström, 2011). This highlights Ricoeur's (1984) argument that the person and their understanding of life are continuously developing and changing over time. Other literature on caring for people that suffer from chronic diseases, described reconciliation as finding harmony with oneself, as a move forward towards acceptance (Delmar et al., 2005) and as a revaluation of one's earlier identity as well as earlier life (Asbring, 2001). This bears a resemblance to the concept of PTG referred to earlier in that the emphasis is on reporting growth outcomes in the aftermath of traumatic circumstances (Tedeschi \& Calhoun, 2004).

Stephen Fraley (2001) looked at the meaning of reconciliation for prisoners serving long sentences. Fraley (2001) posits that it can be very difficult for criminal offenders who are serving long sentences to achieve reconciliation with those to whom they brought suffering and pain, especially if their offending has been homicide and direct reconciliation with the victim is therefore impossible. Nonetheless, Fraley (2001) reported that offenders often attempt to make amends in other aspects of their life and the lives of others. For example, strengths-based activities, such as helping others who are less far along in the recovery/reintegration process can allow offenders or ex-offenders to attempt to reconcile with society for their past crimes (Maruna and LeBel, 2009; Aresti et al., 2010; LeBel, 2012; LeBel et al., 2015). Of particular interest, Rotella, Richeson, and McAdams (2015) suggest that engaging in redemption narratives can encourage reconciliatory intentions among perpetrators.

Additional insights can be gained from the framework of 'identity, meaning, control and belonging' proposed by Ashforth (2001) for understanding organizational transitions. Ashforth's ideas center upon how one disengages from one role (role exit) and engages in another (role entry). As the individual makes a transition into, within or out of a role they must find working reconciliations in relation to finding purpose and significance in the role (meaning) as well as gaining understanding of the nature of the role (Brief and Nord, 1990; Morin, 1995). Moreover, for the role to consolidate, Ashforth (2001) argues that the motive for control, a drive to master and to exercise influence in the role and the motive for belonging, a desire for connectedness with and commitment to others (similar to generative goals) are both important for the role to gain permanence and predominately reflect the importance of the shared social identity. In the new role 
the person engages with 'self-in-role' schemas that direct thought, feelings and action. The implication is that defining oneself in terms of role identity requires making sense of oneself in the new role.

This understanding is pertinent to the desistance literature, which underscores the individual as an active agent of their own destiny (Vaughan, 2007). It is the individual that chooses, for example, to engage in employment; this aids the individual to adjust to the expectations of the new role and facilitates the enactment of law-abiding behaviors (Laub \& Sampson, 2003). Additionally, emotions play a crucial role in directing (Archer, 1995) the individual towards the values and concerns most relevant to them and encourage reconciliation with a denounced past, hopeful present and ideal future. Even major psychological symptoms can be seen as a form of sense- making that is equally dependent on inherently social processes (Kyselo, 2016).

\section{Consequences and adjustment following incomprehensibility}

The emergence of insightful, coherent and constructive meaning-making is not evident for every offender who has committed homicide. It is not uncommon for an offender to engage in 'techniques of neutralization' such as denial of responsibility, denial of injury, denial of the victim, condemnation of condemners, and the appeal to higher loyalties (Sykes \& Matza, 1957). Engaging in neutralization might be unsurprising, especially in the initial aftermath of committing homicide, as remorse can be painful, not least because of the level of shame that is instigated in the aftermath of such deeds (Gobodo-Madikizela, 2002). Neutralization techniques are, on the other hand, also important as they aid the formation of narrative coherence and the development of self-narrative (Maruna \& Copes, 2005). Neutralization techniques are ways of warding off shame, in the face of an individual believing that their life has been potentially worthless (Lofland, 1969). Defining the self in terms of shame and internalizing a negative identity (e.g. I am bad) results "in a loss of face, loss of a sense of self-continuity, and feelings of ego fragmentation and coming apart in terms of moral integrity" (Wilson, Droždek, \& Turkovic, 2006, pg. 133).

Enduring struggles with painful feelings of social shame, humiliation and feelings unworthiness due to awareness of wrongful behavior (Velotti, Elison, \& Garofalo, 2014) may result in social connections becoming removed and distant, in particularly with family members (Edin, Nelson, \& Paranal, 2004). Jean Baker Miller (1988) coined the term "condemned isolation" to describe the hazards of isolation and aloneness that create remoteness from human connection and feelings of immobilization regarding reconnection with others. This entrapment in functioning can be the result of intensification of psychopathology (i.e. PTSD) and identification with shame, as the dimensions of the self-structure (i.e. continuity, coherence, connection, autonomy, energy, vitality) continue to be negatively affected (Wilson, 2005). Twenge, Catanese, and Baumeister (2003) also highlighted how meaningful thought is disabled as social exclusion comes to the fore. With this might come an exacerbation of loneliness in the wake of 
trauma (Stein \& Tuval-Mashiach, 2015) which can be reinforced through the failure of being able to articulate painful experiences (Bar-On, 1999; Scarry, 1985).

As such, the antidote to shame is a system of nurturing support and communication which enables the restoration of a sense of belonging (Burnett \& Maruna, 2006). Specifically, individuals in this situation require what Adshead (2002) delineated as a 'secure base', entailing healthy therapeutic boundaries, ways of regulating affect both in staff and patients and the importance of reflective spaces for staff among other elements. A secure base also mirrors the conditions of support and scope for a degree of autonomy necessary for the exploration associated with secure attachment (Needs \& Adair-Stantiall, in press). The role of supervision has been highlighted as crucial for renewed exploration and development, when working with people presenting with challenging behaviors (Moore, 2012; Adshead et al., 2015; Adshead et al., 2012 ; Bowers, 2002) and especially when there are concerns of being a victim of an attack and/or of being identified as the aggressor (Doctor, 2008). Democratic therapeutic communities (DTC), that house residents identified as personality disordered, have been described as environments that promote change and encourage some of the aspects mentioned above by helping the men to come to terms with their offender identity and its origins within a "supportive and affirmative social climate" (Shuker, 2010, p.463).

\section{Conclusion: Implications for practice, policy and research}

This paper has suggested that there is evidence that meaning-making is both a process and an outcome that can be applied to those who perpetrate violent offences, such as homicide. A violent and fatal offence can be traumatic for the perpetrator in that it is sudden, unexpected, out of the ordinary, and threatens one's future life and general wellbeing (McCann and Pearlman, 1990; Tennen and Affleck, 1990). It also constitutes a "moral injury" in the sense described by Litz et al. (2009).

Literature lends support for reinforcing the rehabilitative process through the development of new resolutions of identity, encouraging agency, and providing opportunities for healthy connections to develop. The roles of pre trauma vulnerability, trauma-related and post-trauma factors in relation to the evolving narrative and meaning making are also aspects of value in informing therapeutic interventions and rehabilitative aims. We have suggested that it is vital to explore the meaning that violent offenders make of their offences because of the opportunities for psychological growth in suffering and trauma which in turn provides information about how to promote safety and monitor risk of violence in future.

We conclude that the value in the process of meaning reconstruction for homicide perpetrators and its role in relation to wellbeing, and possible risk reduction, supports the provision of opportunities for perpetrators to critically reflect upon their narrative and share their life story. Practice-based insights as advanced by Ward and colleagues (Ward, 2002; Ward et al., 2007; Ward and Marshall, 2007) through the Good Lives Model (GLM), support this proposition. 
There is a danger that this work may be interpreted as ignoring the suffering of the victims, or families or the wrong and harm done by perpetrators. However, we do not believe that attention to the perpetrator implies lack of attention to the victim, just as there is a difference between explaining and excusing. Indeed, in our work so far, we have found that offenders gain more insight and sense of personal responsibility if their attempts at meaning making are encouraged in a supportive context than if they are left to 'do their time' in silence in a manner which can discourage reflection, renewed exploration and connectedness to others.

\section{Acknowledgement}

Many thanks to Dr Dominic Pearson and Dr Treena Jingree for fruitful discussions on earlier drafts, and to Professor Estelle Moore, Mr Tony Attard, Mr Ronald Zammit and Miss Laura Bottini for encouragement and for strengthening this manuscript through their reviews.

\section{References}

Adshead, G. (2002). Three degrees of security: Attachment and forensic institutions. Criminal Behaviour and Mental Health, 12, 31-45.

Adshead, G. (2003). Three degrees of security. In F. Pfafflin, \& G. Adshead (Eds.), A matter of security: Attachment theory and forensic psychiatry and psychotherapy (pp. 47-66). London: Jessica Kingsley. Adshead, G. (2014). Safety in numbers: Group therapy-based index offence work in secure psychiatric care. Psychoanalytic psychotherapy, 29(3), 295-310.

Adshead, G., Bose, S., \& Cartwright, J. (2008). Life after death: Group therapy with men who have killed. In R. Doctor (Ed.), Murder: A psychotherapeutic investigation (pp. 9-33). London, England: Karnac Books. Adshead, G., Bose, S., \& Helliwell, S. (2012). Index offence work for homicide: Reflective therapy groups for men who have killed. Forensic Update, 105. (pp. 39-45). The British Psychological Society, 39-45. Adshead, G., Ferrito, M., \& Bose, S. (2015). Recovery after homicide narrative shifts in therapy with homicide perpetrators. Criminal Justice and Behaviour, 42(1), 70-81.

Anderson, H. (1997). Self: Narrative, identity, and agency. New York: Basic Books.

Androff, D. (2010). Truth and reconciliation commissions (TRCs): An international human rights intervention and its connection to social work. British Journal of Social Work, 40(6), 1960-1977.

Archer, M. S. (1995). Realist social theory: The morphogenetic approach. Cambridge University press. Aresti, A., Eatough, V., \& Brooks-Gordon, B. (2010). Doing time after time: An interpretative phenomenological analysis of reformed ex-prisoners' experiences of self-change, identity and career opportunities. Psychology, Crime \& Law, 16, 169-190.

Armour, M. (2003). Meaning-making in the aftermath of homicide. Death Studies, 27, 519-540.

Asbring, P. (2001). Chronic illness - A disruption in life: Identity-transformation among women with chronic fatigue syndrome and fibromyalgia. Journal of Advanced Nursing, 34, 312-319. 
Asencio, E. K., \& Burke, P. J. (2011). Does incarceration change the criminal identity? A synthesis of labelling and identity theory perspectives on identity change. Sociological Perspectives, 54(2), $163-182$.

Ashforth, B. E. (2001). Role transitions in organizational life: An identity-based perspective. Mahwah, NJ: Lawrence Erlbaum Associates.

Baird, R. M. (1985). Meaning in life: Discovered or created? Journal of Religion and Health, 24, $117-124$. Bar-On, D. (1999). The indescribable and the undiscussable: Reconstructing human discourse after trauma. Budapest, Hungary: Central European Universities Press.

Baumeister, R. F. (1991). Meanings of life. New York, NY: Guilford.

Baumeister, R. F. (1994). The crystallization of discontent in the process of major life change. In T. F. Heatherton, \& J. L. Weinberger (Eds.), Can personality change? (pp. 281-297). Washington, DC: American Psychological Association.

Baumeister, R. F., \& Leary, M. R. (1995). The need to belong: Desire for interpersonal attachments as a fundamental human motivation. Psychological Bulletin, 10, 497-529.

Beck, A. T., Freeman, A., Davis, D. D., Pretzer, J., Fleming, B., Arntz, A., ... Renton, J. (2004). Cognitive therapy of personality disorders (2nd ed.). New York: Guilford Press.

Bonanno, G. A., Papa, A., \& O'Neill, K. (2001). Loss and human resilience. Applied and Preventive Psychology, 10, 193-206.

Bowers, L. (2002). Dangerous and severe personality disorder: Response and role of the psychiatric team. Psychology Press.

Brewin, C. R. (2001). A cognitive neuroscience account of posttraumatic stress disorder and its treatment. Behaviour Research and Therapy, 39, 373-393.

Brewin, C. R., Dagleish, T., \& Joseph, S. (1996). A dual representation theory of posttraumatic stress disorder. Psychological Review, 103, 670-686.

Brickman, P., Rabinowitz, V. C., Karuza, J., Coates, D., Cohn, E., \& Kidder, L. (1982). Models of helping and coping. American Psychologist, 37, 368-384.

Brief, A., \& Nord, W. F. (1990). Meanings of occupational work. Lexington, MA: Lexington Books. Brinn, A. J., \& Auerbach, C. F. (2015). The warrior's journey: Sociocontextual meaningmaking in military transitions. Traumatology, 21(2), 82.

Broman, E. L., Hamilton, V. L., \& Hoffman, W. S. (2001). Stress and distress among the unemployed: Hard times and vulnerable people. New York: Kluwer Academic.

Brunning, J. (1982). The group psychotherapy of murderers. Prison Medical Journal, 23, 6-10.

Bryant, R. A., \& Harvey, A. G. (2000). Acute stress disorder: A handbook of theory, assessment, and treatment. Washington, D.C: American Psychological Association.

Burnell, K., Coleman, P., \& Hunt, N. (2011). Achieving narrative coherence following traumatic war experience: The role of social support. In G. Kenyon, E. Bohlmeijer, \& W. Randall (Eds.), Storying later life: Perspectives, investigations, and interventions in narrative gerontology (pp. 195-212). New York: Oxford University Press. 
Burnell, K. J., Coleman, P. G., \& Hunt, N. (2006). Falklands war veterans' perceptions of social support and the reconciliation of traumatic memories. Aging \& Mental Health, 10(3), 282-289.

Burnell, K. J., Coleman, P. G., \& Hunt, N. (2010). Coping with traumatic memories: Second world war veterans' experiences of social support in relation to the narrative coherence of war memories. Ageing and Society, 30, 57-78.

Burnett, R., \& Maruna, S. (2006). The kindness of prisoners: Strengths-based resettlement in theory and action. Criminology \& Criminal Justice, 6, 83-106.

Canter, D. (1994). Criminal shadows: Inside the mind of the serial killer. HarperCollins.

Canter, D., \& Youngs, D. (2012). Narratives of criminal action and forensic psychology. Legal and Criminological Psychology, 17, 262-275.

Chandler, M. J., \& Proulx, T. (2008). Personal persistence and persistent people: Continuities in the lives of individuals and whole cultural communities. In F. Sani (Ed.), Selfcontinuity: Individual and collective perspectives. New York: Taylor \& Francis.

Charuvastra, A., \& Cloitre, M. (2008). Social bonds and posttraumatic stress disorder. Annual Review of Psychology, 59, 301.

Clark, D. D., \& Crossland, J. (1985). Action systems: An introduction to the analysis of complex behavior. USA: Methuen \& Co.

Cohen, S., \& Wills, T. A. (1985). Stress, social support, and the buffering hypothesis. Psychological Bulletin, $98,310-357$.

Coid, J. (1992). DSM-III diagnosis in criminal psychopaths: A way forward. Criminal Behaviour and Mental Health, 2, 78-94.

Cox, M. (Ed.). (1974). Remorse and reparation. London: Jessica Kingsley Publishers.

Cruwys, T., Haslam, S. A., Dingle, G. A., Jetten, J., Hornsey, M. J., Chong, E. D., \& Oei, T. P. (2014). Feeling connected again: Interventions that increase social identification reduce depression symptoms in community and clinical settings. Journal of Affective Disorders, 159, 139-146.

Cullen, E., \& Newell, T. (1999). Murderers and life imprisonment: Containment, treatment, safety, and risk. Winchester: Waterside Press.

Curle, C. E. (1989). An investigation of reaction to having killed amongst male homicide patients resident in a maximum security hospital. (Report to the Department of Health (Broadmoor Hospital library: unpublished report)).

Currier, J. M., Holland, J. M., \& Neimeyer, R. A. (2006). Sense-making, grief, and the experience of violent loss: Toward a mediational model. Death Studies, 30, 403-428.

Day, A., Howells, K., Heseltine, K., \& Casey, S. (2003). Alcohol use and negative affect in the offence cycle. Criminal Behaviour and Mental Health, 13(1), 45-48.

De Jaegher, H., \& Froese, T. (2009). On the role of social interaction in individual agency. Adaptive Behavior, 17(5), 444-460. 
Delmar, C., Boje, T., Dylmer, D., Forup, L., Jakobsen, C., Moller, M., \& Pedersen, B. (2005). Achieving harmony with oneself: Life with a chronic illness. Scandinavian Journal of Caring Sciences, 19, $204-212$. Doctor, R. (Ed.). (2008). Murder: A psychotherapeutic investigation. Karnac Books.

Drennan, G., \& Alred, D. (Eds.). (2011). Secure Recovery: Approaches to recovery in forensic mental health settings. Issues in Forensic Psychology. London: Routledge.

DSM-5 American Psychiatric Association (2013). Diagnostic and statistical manual of mental disorders. Arlington: American Psychiatric Publishing.

Duck, S. W. (Ed.). (1982). Personal relationships 4: Dissolving personal relationships. London: Academic Press.

Dunlop,W., Lawrence, L.,Walker, J., \& Thomas, K.W. (2015). The redemptive story: A requisite for sustaining prosocial behavioral patterns following traumatic experiences. Journal of Constructivist Psychology, 28, $228-242$.

Edin, K., Nelson, T. J., \& Paranal, R. (2004). Fatherhood and incarceration as potential turning points in the criminal careers in unskilled men. In M. E. Pattillo, D.Weiman, \& B. Western (Eds.), Imprisoning America: The social effects of mass incarceration (pp. 46-75). New York, NY: Russell Sage.

Edmonds, S., \& Hooker, K. (1992). Perceived changes in life meaning following bereavement. Omega, 25, 307-318.

Ehlers, D. M., \& Clark, A. (2000). Cognitive model of posttraumatic stress disorder. Behaviour Research and Therapy, 38, 319-345.

Elisha, E., Idisis, Y., \& Ronel, N. (2013). Positive criminology and imprisoned sex offenders: Demonstration of a way out from a criminal spin through acceptance relationships.

Journal of Sexual Aggression, 19, 66-80.

Emmons, R., \& King, L. A. (1988). Conflict among personal strivings: Immediate and long term implications for psychological and physical well-being. Journal of Personality and Social Psychology, 54, 1040-1048.

Erikson, E. H. (1950). Childhood and society. New York, NY: Norton.

Farrall, S., \& Calverley, A. (2006). Understanding desistance from crime: Theoretical directions in resettlement and rehabilitation. Maidenhead: Open University Press.

Ferrito, M., Vetere, A., Adshead, G., \&Moore, E. (2012). Life after homicide: Accounts of recovery and redemption of offender patients in a high security hospital - A qualitative study. Journal of Forensic Psychiatry and Psychology, 23, 327-344.

Foa, E. B., \& Riggs, D. S. (1993). Post-traumatic stress disorder in rape victims. American Psychiatric Press Review of Psychiatry, 12, 273-303.

Foa, E. B., \& Rothbaum, B. O. (1998). Treating the trauma of rape: Cognitive behavioral therapy for PTSD. New York: Guilford Press.

Fraley, S. (2001). The meaning of reconciliation for prisoners serving long sentences. Contemporary Justice Review, 4, 59-74.

Frankl, V. E. (1984). Man's search for meaning. New York: Washington Square Press. 
Gilbert, D. T. (2006). Stumbling on happiness. New York: NY: Knopf.

Gillies, J., \& Neimeyer, R. A. (2006). Loss, grief and the search for significance: Toward a model of meaning reconstruction in bereavement. Journal of Constructivist Psychology, 19, 31-65.

Giordano, P. C., Cernkovich, S. A., \& Rudolph, J. L. (2002). Gender, crime, and desistance: Towards a theory of cognitive transformation. American Journal of Sociology, 107, 990-1064.

Gobodo-Madikizela, P. (2002). Remorse, forgiveness, and rehumanization: Stories from South Africa. Journal of Humanistic Psychology, 42, 7-32.

Goffman, E. (1963). Stigma: Notes on the Management of Spoiled Identity. Englewood Cliffs, NJ: PrenticeHall.

Gottfredson, D. C., \& Hirschi, T. (1990). A general theory of crime. Stanford, CA: Stanford University Press. Graham, J., \& Bowling, B. (1995). Young people and crime. Home office research study. 145. (London). Guse, T., \& Hudson, D. (2014). Psychological strengths and posttraumatic growth in the successful reintegration of South African ex-offenders. International Journal of Offender Therapy and Comparative Criminology, 58, 1449-1465.

Gustafsson, L., Wiklund-Gustin, L., \& Lindström, U.Å. (2011). The meaning of reconciliation: women's stories about their experience of reconciliation with suffering from grief. Scandinavian Journal of Caring Sciences, 25(3), 525-532.

Harré, R. (1975). Causal powers: A theory of natural necessity.

Harry, B., \& Resnick, P. J. (1986). Post-traumatic Stress Disorder in Murderers. Journal of Forensic Sciences, 31(2), 609-613.

Harvey, J. H. (2008). Growth through loss and adversity in close relationships. In S. Joseph, \& P. Linley (Eds.), Trauma, recovery, and growth: Positive psychological perspectives on posttraumatic stress (pp. 125-143). Hoboken, NJ: Wiley.

Heads, T., Taylor, P., \& Leese, M. (1997). Childhood experiences of patients with schizophrenia and a history of violence: A special hospital sample. Criminal Behavior and Mental Health, 7, 117-130.

Heintzelman, S. J., \& King, L. A. (2013). On knowing more than we can tell: Intuitive processes and the experience of meaning. The Journal of Positive Psychology, 8(6), 471-482.

Hillbrand, M., \& Young, J. L. (2008). Instilling hope into forensic treatment: The antidote to despair and desperation. The Journal of the American Academy of Psychiatry and the Law, 36, 90-94.

Horne, A. S. (1999). Reflections on remorse in forensic psychotherapy. In M. Cox (Ed.), Remorse and reparation (pp. 9-18). London: Jessica Kingsley Publishers.

Horowitz, M. (1986). Stress-response syndromes: A review of posttraumatic and adjustment disorders. Hospital \& Community Psychiatry, 37, 241-249.

Hoyle, R. H., \& Sherrill,M. R. (2006). Future orientation in the self-system: Possible selves, self-regulation, and behavior. Journal of Personality, 74(6), 1673-1696.

Hunt, N. C. (2010). Memory, war and trauma. Cambridge University Press. 
Janoff-Bulman, R. (1992). Shattered assumptions: Towards a new psychology of trauma. New York, NY: Free Press.

Janoff-Bulman, R., \& McPherson, C. (1997). The impact of trauma on meaning: From meaningless world to meaningful life. In C. Brewin (Ed.), The transformation of meaning in psychological therapies (pp. 91-106). New York, NY: Wiley.

Jetten, J., Haslam, C., Haslam, S. A., Dingle, G., \& Jones, J. M. (2014). How groups affect our health and wellbeing: The path from theory to policy. Social Issues and Policy Review, 8(1), 103-130.

Jetten, J., O'Brien, A., \& Trindall, N. (2002). Changing identity: Predicting adjustment to organizational restructure as a function of subgroup and superordinate identification. British Journal of Social Psychology, $41,281-297$.

Joseph, S., \& Linley, P. A. (2005). Positive adjustment to threatening: An organismic valuing theory of growth following adversity. Review of General Psychology, 9(3), 262-280.

Joseph, S., Linley, P. A., \& Harris, G. J. (2005). Understanding positive change following trauma and adversity: Structural clarification. Journal of Loss \& Trauma, 10, 83-96.

Katz, J. (1988). Seductions of crime: Moral and sensual attractions in doing evil. USA: Basic.

King, D. W., Taft, C., King, L. A., Hammond, C., \& Stone, E. R. (2006). Directionality of the association between social support and posttraumatic stress disorder: A longitudinal investigation. Journal of Applied Social Psychology, 36(12), 2980-2992.

Klinger, E. (1998). The search for meaning in evolutionary perspective and its clinical implications. In P. T. P.Wong, \& P. S. Fry (Eds.), The human quest for meaning (pp. 27-50). Mahwah, NJ: Erlbaum. Kyselo, M. (2016). The enactive approach and disorders of the self - the case of schizophrenia. Phenomenology and the Cognitive Sciences, 15(4), 591-616.

Lambert, N. M., Stillman, T. F., Hicks, J. A., Kamble, S., Baumeister, R. F., \& Fincham, F. D. (2013). To belong is to matter sense of belonging enhances meaning in life. Personality and Social Psychology Bulletin, 39, $1418-1427$.

Laub, J., \& Sampson, R. (2003). Shared beginnings, divergent lives: Delinquent boys to age seventy. Cambridge, MA: Harvard University Press.

Leary, M. R. (1990). Responses to social exclusion: Social anxiety, jealousy, loneliness, depression, and low self-esteem. Journal of Social and Clinical Psychology, 9, 221-229.

LeBel, T. P. (2012). Invisible stripes? Formerly incarcerated persons' perceptions of stigma. Deviant Behavior, 33, 89-107.

LeBel, T., Richie,M., \&Maruna, S. (2015). Helping others as a response to reconcile a criminal past: The role of the wounded healer in prisoner re-entry programs. Criminal Justice and Behavior, 42(1), 108-120. Lemert, E.M. (1967). Human deviance, social problems and social control. Englewood Cliffs, NJ: PrenticeHall.

Lerner, M. J. (1980). The belief in a just world: A fundamental delusion. New York, NY: Plenum Press. 
Lindqvist, P., Leifman, A., \& Eriksson, A. (2007). Mortality among homicide offenders: A retrospective population-based long-term follow-up. Criminal Behaviour and Mental Health, 17, 107-112.

Litz, B. T., Stein, N., Delaney, E., Lebowitz, L., Nash, W. P., Silva, C., \& Maguen, S. (2009). Moral injury and moral repair in war veterans: A preliminary model and intervention strategy. Clinical Psychology Review, 29(8), 695-706.

Lofland, J. (1969). Deviance and identity. Englewood Cliffs, NJ: Prentice-Hall.

Lynam, D. R., Wikstrom, P. H., Caspi, A., Moffitt, T. E., Loeber, R., \& Novak, S. (2000). The interaction between impulsivity and neighborhood context on offending: The effects of impulsivity are stronger in poorer neighborhoods. Journal of Abnormal Psychology, 109, 563-574.

Mamali, C., \& Dunn, R. (2011). The interpersonal and interpersonal effects of crucial experiences. Journal of Loss and Trauma: International Perspectives on Stress \& Coping, 16(2), 103-116.

Mapham, A., \& Hefferon, K. (2012). "I used to be an offender-Now I'm a defender": Positive psychology approaches in the facilitation of posttraumatic growth in offenders. Journal of Offender Rehabilitation, 51, 389-413.

Markus, H., \& Nurius, P. (1986). Possible selves. American Psychologist, 41(9), 954-969.

Maruna, S. (1997). Going straight: Desistance from crime and self-narratives of reform. Narrative Study of Lives. 5. (pp. 59-93).

Maruna, S. (2001). Making good. Washington, DC: American Psychological Association.

Maruna, S., \& Copes, H. (2005).What have we learned fromfive decades of neutralization research? Crime and Justice: A Review of Research, 32, 221-320.

Maruna, S., \& LeBel, T. (2003). Welcome home? Examining the "Re-entry court" concept from a strengthsbased perspective. Western Criminology Review, 4(2), 91-107.

Maruna, S., \& Ramsden, D. (2004). Living to tell the tale: Redemption narratives, shame management and offender rehabilitation. In A. Lieblich, D. P. McAdams, \& J. Josselson (Eds.), Healing plots: The narrative basis of psychotherapy (pp. 129-151). Washington, DC: American Psychological Society.

Maruna, S., \& LeBel, T. P. (2009). Strengths-based approaches to reentry: Extra mileage toward reintegration and destigmatization. Japanese Journal of Sociological Criminology, 34, 59-80.

Maruna, S., LeBel, T., \& Lanier, C. (2004). Generativity behind bars: Some 'redemptive truth' about prison society. In E. de St. Aubin, D. McAdams, \& T. Kim (Eds.), The generative society (pp. 131-152). Washington, DC: American Psychological Association.

May, G. (1988). Addiction and grace. San Francisco: Harper \& Row.

McAdams, D. P. (1987). A life-story model of identity. In R. Hogan, \& W. H. Jones (Eds.), Perspectives in personality (pp. 15-50). Greenwich, CT: JAI Press.

McAdams, D. P. (1990). Unity and purpose in human lives: The emergence of identity as the life story. In A. I. Rabin, R. A. Zucker, R. A. Emmons, \& S. Frank (Eds.), Studying persons and lives (pp. 148-200). New York: Springer.

McAdams, D. P. (2001a). The psychology of life stories. Review of General Psychology, 5, 100-122. 
McAdams, D. P. (2001b). The person: An integrated introduction to personality psychology (3rd ed.). Fort Worth, TX: Harcourt College Publishers.

McAdams, D. P. (2006). The redemptive self. Stories Americans live by New York: Oxford University Press. McAdams, D. P., Diamond, A., de St. Aubin, E., \& Mansfield, E. (1997). Stories of commitment: The psychosocial construction of generative lives. Journal of Personality and Social Psychology, 72, 678-694. McAdams, D. P. (1996). Personality, modernity, and the storied self: A contemporary framework for studying persons. Psychological Inquiry, 7, 295-321.

McAdams, D. P., \& Bowman, P. J. (2001). Narrating life's turning points: Redemption and contamination. In D. McAdams, R. Josselson, \& A. Lieblich (Eds.), Turns in the road. Narratives studies of lives in transition (pp. 3-34). Washington DC: APA.

McCann, I. L., \& Pearlman, L. A. (1990). Psychological trauma and the adult survivor. Theory, therapy and transformation New York: Brunner Mazel.

McFarlane, A. C., \& Yehuda, R. (1996). Resilience, vulnerability, and the course of posttraumatic reactions. In B. A. Van der Kolk, A. C. McFarlane, \& L.Weisaeth (Eds.), Traumatic stress: The effects of overwhelming experience onmind, body, and society (pp. 155-181). New York: Basic Books, Guildford Press, NY. Meichenbaum, D. (2006). Resilience and posttraumatic growth: a constructive narrative perspective. In L. Calhoun, \& R. Tedeschi (Eds.), Handbook of Posttraumatic Growth: Research and Practice. Manhaw, NJ: Erlbaum and Associates.

Miller, J. B. (1988). Connections, disconnections and violations. Vol. 33.Wellesley, MA: Stone Center, Wellesley College.

Moffitt, T. E. (1993). Adolescence-limited and life-course persistent antisocial behavior: A developmental taxonomy. Psychological Review, 100, 674-701.

Moore, E. (2012). Personality disorder: Its impact on staff and the role of supervision. Advances in Psychiatric Treatment, 18(1), 44-55.

Morin, E. M. (1995). Organizational effectiveness and the meaning of work. In T. C. Pauchant (Eds.), In search of meaning. Managing for the health of our organizations, our communities, and the natural world (pp. 29-64). San Francisco: Jossey-Bass.

Needs, A., \& Neale, S. (2016). Peer mentoring for veterans within the Hampshire probation trust/southern health NHS foundation trust scheme. A review of relevant research and initial exploration University of Portsmouth: Unpublished report.

Needs, A. (2015). The transition process, trauma and rebuilding resilience. Paper presented at the 3rd Annual Conference on Military Psychology Basingstoke, UK: Wessex Branch, BPS.

Needs, A. (2016). Rehabilitation - Writing a new story. The Psychologist, 29(3), 192-195.

Needs, A., \& Adair-Stantiall, A. (2016). The social context of transitions and rehabilitation. In G. Akerman, A. Needs, \& C. Bainbridge (Eds.), Transforming environments and rehabilitation in custodial settings.

Routledge Books (in press). 
Neimeyer, R. A. (2006a). Re-storying loss: Fostering growth in the posttraumatic narrative. In L. Calhoun, \& R. Tedeschi (Eds.), Handbook of posttraumatic growth: Research and practice (pp. 68-80). Mahwah, NJ: Erlbaum.

Neimeyer, R. A. (Ed.). (2001). Meaning reconstruction and the experience of loss. Washington, DC: American Psychological Association.

Neimeyer, R. A. (2006b). Complicated grief and the reconstruction of meaning: Conceptual and empirical contributions to a cognitive-constructivist model. Clinical Psychology: Science and Practice, 13, 141-145. Orbuch, T. L. (Ed.). (1992). Close relationship loss: Theoretical approaches. New York, NY: Springer Verlag. Ozer, E. J., Best, S. R., Lipsey, T. L., \&Weiss, D. S. (2008). Predictors of posttraumatic stress disorder and symptoms in adults: A meta-analysis. Psychological Bulletin, 129, 52-73.

Papanastassiou, M., Waldron, G., Boyle, J., \& Laurence, P. (2004). Post-traumatic stress disorder in mentally ill perpetrators of homicide. The Journal of Forensic Psychiatry \& Psychology, 15(1), 66-75.

Park, C. L. (2010).Making sense of the meaning literature: An integrative review of meaning-making and its effect on adjustment to stressful life events. Psychological Bulletin, 136, 257-301.

Park, C. L., \& Ai, A. L. (2006). Meaning-making and growth: New directions for research on survivors of trauma. Journal of Loss and Trauma, 11, 389-407.

Park, C. L., \& Folkman, S. (1997). Meaning in the context of stress and coping. Review of General Psychology, 2, 115-144.

Parker, T. (1995). Life after life: Interviews with twelve murderers. London: Harper Collins.

Paternoster, R., \& Bushway, S. (2009). Criminology desistance and the feared self: Toward an identity theory of criminal desistance. The Journal of Criminal Law and Criminology, 99, 1103-1156.

Pennebaker, J.W., \& Seagal, J. D. (1999). Forming a story: The health benefits of narrative. Journal of Clinical Psychology, 55, 1243-1254.

Perrin, C., \& Blagden, N. (2014). Accumulating meaning, purpose and opportunities to change 'drip by drip': The impact of being a listener in prison. Psychology, Crime \& Law, 20(9), 902-920.

Perry, B. D. (1999). Memories of fear: How the brain stores and retrieves physiological states, feelings, behaviors and thoughts from traumatic events. In J. Goodwin, \& R. Attial (Eds.), Splintered reflections: Images of the body in trauma (pp. 26-47). Basic Books, NY: New York.

Peteet, J. R. (1993). A closer look at the role of spiritual approach in addictions treatment. Journal of Substance Abuse Treatment, 10, 263-267.

Pham, T. H., \& Willocq, L. (2013). Evaluation of traumatic stress in incarcerated homicide offenders. Acta Psychiatrica Belgica, 113(2), 136-153.

Polaschek, D. L. L., Calvert, S.W., \& Gannon, T. A. (2009). Linking violent thinking: Implicit theory-based research with violent offenders. Journal of Interpersonal Violence, 24(1), 1-22.

Polkinghorne, D. E. (1988). Narrative knowing and human sciences. New York, NY: State University of New York Press. 
Pollock, P. H. (1999). When the killer suffers: Post-traumatic stress reactions following homicide. Legal and Criminological Psychology, 4(2), 185-202.

Presser, L. (2008). Been a heavy life. Stories of violent men Urbana, IL: University of Illinois Press.

Presser, L. (2009). The narratives of offenders. Theoretical Criminology, 13(2), 177-200.

Radzik, L. (2009). Making amends: Atonement in morality, law, and politics. Oxford University Press Inc. Ricoeur, P. (1984). Time and narrative. Vol. 1.Chicago: University of Chicago.

Rosen, G. M., \& Lilienfeld, S. O. (2008). Posttraumatic stress disorder: An empirical evaluation of core assumptions. Clinical Psychology Review, 28(5), 837-868.

Rotella, K. N., Richeson, J. A., \& McAdams, D. P. (2015). Groups' search for meaning: Redemption on the path to intergroup reconciliation. Group Processes \& Intergroup Relations, 18(5), 696-715.

Rotenberg, M. (1987). Re-biographing and deviance. Psychotherapeutic narrativism and the midrash Praeger Publishers.

Rynearson, E. K. (1984). Bereavement after homicide: A descriptive study. American Journal of Psychiatry, 141(11), 1452-1454.

Sadeh, N., \& Karniol, R. (2012). The sense of self-continuity as a resource in adaptive coping with job loss. Journal of Vocational Behavior, 80, 93-99.

Sampson, R. H., \& Laub, J. H. (1993). Crime in the making. Pathways and turning points through life Cambridge, MA: Harvard University Press.

Sampson, R. J., \& Laub, J. H. (2003). Life-course desisters? Trajectories of crime among delinquent boys followed to age 70 . Criminology, 41(3), 555-592.

Sampson, R. J., \& Laub, J. H. (2005). When prediction fails: From crime-prone boys to heterogeneity in adulthood. The Annals of the American Academy of Political and Social Science, 602(1), 73-79.

Sani, F. (Ed.). (2008). Individual and collective self-continuity. Mahwah, NJ: Erlbaum.

Scarry, E. (1985). The body in pain. The making and unmaking of the world. New York, NY: Oxford University Press.

Schmid, T. J., \& Jones, R. S. (1991). Suspended identity: Identity transformation in a maximum security prison. Symbolic Interaction, 14, 415-432.

Schur, E. M. (1971). Labeling deviant behavior. New York: Harper and Row.

Sedikides, C., Wildschut, T., Routledge, C., \& Arndt, J. (2015). Nostalgia counteracts self-discontinuity and restores self-continuity. European Journal of Social Psychology, 45, 52-61.

Seligman, M. E. P., \& Csikszentmihalyi, M. (2000). Positive psychology: An introduction. American Psychologist, 55, 5-14.

Sharp, C., Fonagy, P., \& Allen, J. G. (2012). Posttraumatic stress disorder: A social-cognitive perspective. Clinical Psychology: Science and Practice, 19(3), 229-240.

Shuker, R. (2010). Forensic therapeutic communities: A critique of the treatment model and evidence base. The Howard Journal of Criminal Justice, 49, 463-477. 
Singer, J. A., \& Salovey, P. (1993). The remembered self. Emotion and memory in personality New York: The Free Press.

Singer, J. B. (2002). Living in the amber cloud: A life story analysis of a heroin addict. In D. P. McAdams, R. Josselson, \& A. Lieblich (Eds.), Turns in the road: Narrative studies of lives in transition (pp. 253-277) (2 ${ }^{\text {nd }}$ ed.). Washington, DC: American Psychological Association.

Sippel, L. M., Pietrzak, R. H., Charney, D. S., Mayes, L. C., \& Southwick, S. M. (2015). How does social support enhance resilience in the trauma-exposed individual? Ecology and Society, 20(4).

Skowyra, K. R., \& Cocozza, J. J. (2007). Blueprint for change. A comprehensive model for the identification and treatment of youth with mental health needs in contact with the juvenile justice system Policy Research Associates, Inc.

Smith, C. A., Ireland, T. O., \& Thornberry, T. P. (2005). Adolescent maltreatment and its impact on young adult antisocial behavior. Child Abuse \& Neglect, 29(10), 1099-1119.

Sparks, C. (1999). Prisoners' views of the lifer system: Policy vs reality. London: The prison reform trust. Stein, K. F., \& Markus, H. R. (1996). The role of the self in behavioral change. Journal of Psychotherapy Integration, 6(4), 349-384.

Stein, J. Y., \& Tuval-Mashiach, R. (2015). Loneliness and isolation in life-stories of Israeli veterans of combat and captivity. Psychological trauma: Theory, Research, Practice, and Policy, 7(2), 122-130.

Stevens, A. (2012). 'I am the person now I was always meant to be': Identity reconstruction and narrative reframing in therapeutic community prisons. Criminology \& Criminal Justice: An International Journal, 12(5), 527.

Stroebe, M. S., Stroebe, W., \& Hanson, R. O. (Eds.). (1993). Handbook of bereavement: Theory, research, and intervention. Cambridge, England: Cambridge University Press.

Sykes, G. M., \& Matza, D. (1957). Techniques of neutralization: A theory of delinquency. American Sociological Review, 22, 664-670.

Taylor, S. (1989). Positive illusions: Creative self-deception and the healthy mind. New York, NY: Basic Books.

Taylor, T. F. (2015). The influence of shame on posttrauma disorders: Have we failed to see the obvious? European Journal of Psychotraumatology, 6. http://dx.doi.org/10.3402/ejpt.v6.28847.

Tedeschi, R. G., \& Calhoun, L. G. (2004). Posttraumatic growth: Conceptual foundations and empirical evidence. Psychological Inquiry, 15, 1-18.

Tennen, H., \& Affleck, G. (1990). Blaming others for threatening events. Psychological Bulletin, 108, 209232.

Thomas, C., Adshead, G., \& Mezey, G. (1994). Case report: Traumatic responses to child murder. Journal of Forensic Psychiatry, 5(1), 168-176.

Trenvåg, O., \& Kristoffersen, K. (2008). Experience of being the spouse/cohabitant of a person with bipolar affective disorder: A cumulative process over time. Scandinavian Journal of Caring Sciences, 22, 5-11. 
Twenge, J.M., Baumeister, R. F., DeWall, C. N., Ciarocco, N. J., \& Bartels, J.M. (2007a). Social exclusion decreases prosocial behavior. Journal of Personality and Social Psychology, 92(1), 56-66.

Twenge, J. M., Baumeister, R. F., Tice, D. M., \& Stucke, T. S. (2001). If you can't join them, beat them: Effects of social exclusion on aggressive behavior. Journal of Personality and Social Psychology, 81(6), 10581069.

Twenge, J. M., Catanese, K. R., \& Baumeister, R. F. (2003). Social exclusion and the deconstructed state: Time perception, meaninglessness, lethargy, lack of emotion, and self-awareness. Journal of Personality and Social Psychology, 85, 409-423.

Twenge, J. M., Zhang, L., Catanese, K. R., Dolan-Pascoe, B., Lyche, L. F., \& Baumeister, R. F. (2007b). Replenishing connectedness: Reminders of social activity reduce aggression after social exclusion. British Journal of Social Psychology, 46, 205-224.

Uggen, C., Manza, J., \& Behrens, A. (2004). "Less than the average citizen": Stigma, role transition and the civic reintegration of convicted felons. In S. Maruna, \& R. Immarigeon (Eds.), After crime and punishment. Exoffender reintegration and desistance from crime. (pp. 261-293). Cullompton, Devon: Willan Publishing. Van der Kolk, B. A. (2007). The complexity of adaptation to trauma: Self-regulation, stimulus discrimination, and characterological development. In B. A. Van der Kolk, A. C. McFarlane, \& L. W. Weisaeth (Eds.), Traumatic stress: The effects of overwhelming experience on mind, body, and society (pp. 182-213). New York: Guildford Press.

Van der Kolk, B. A., McFarlane, A. C., \& Van der Hart, O. (1996). A general approach to treatment of posttraumatic stress disorder. In B. van der Kolk, A. C. McFarlane, \& L. Weisaeth (Eds.), Traumatic stress: The effects of overwhelming experience on mind, body, and society (pp. 417-440). New York: Guilford, NY. Van der Kolk, B. A., McFarlane, A. C., \& Van der Hart, O. (2007). A general approach to treatment of posttraumatic stress disorder. In B. A. Van der Kolk, A. C. McFarlane, \& L. Weisaeth (Eds.), Traumatic stress: The effects of overwhelming experience on mind, body, and society (pp. 417-440). New York: Guildford Press.

Van Ginneken, E. F. (2014). Making sense of imprisonment narratives of posttraumatic growth among female prisoners. International Journal of Offender Therapy and Comparative Criminology, 1-20. Varela, F. J. (1979). Principles of biological autonomy. New York: Elsevier. Vaughan, B. (2007). The internal narrative of desistance. British Journal of Criminology, 47, 309-404. Velotti, P., Elison, J., \& Garofalo, C. (2014). Shame and aggression: Different trajectories and implications. Aggression and Violent Behavior, 19, 454-461.

Warburton, W. A., Williams, K. D., \& Cairns, D. R. (2006).When ostracism leads to aggression: The moderating effects of control deprivation. Journal of Experimental Social Psychology, 42, 213-220. Ward, T. (2000). Sexual offenders' cognitive distortions as implicit theories. Aggression and Violent Behavior, 5, 491-507.

Ward, T. (2002). Good lives and the rehabilitation of offenders: Promises and problems. Aggression and Violent Behavior, 7, 513-528. 
Ward, T., \& Marshall, W. L. (2007). Narrative identity and offender rehabilitation. International Journal of Offender Therapy and Comparative Criminology, 51, 279-297.

Ward, T., Mann, R. E., \& Gannon, T. A. (2007). The good lives model of offender rehabilitation: Clinical implications. Aggression and Violent Behavior, 12, 87-107.

Weiss, R. S. (1988). Loss and recovery. Journal of Social Issues, 44, 37-52.

West, A. G., \& Greenall, P. V. (2011). Incorporating index offence analysis into forensic clinical assessment. Legal and Criminological Psychology, 16, 144-159.

Wethington, E. (2003). Turning points as opportunities for psychological growth. In C. Keyes, \& J. Haidt (Eds.), Flourishing, positive psychology and the life well-lived (pp. 37-53) (2nd ed.). Washington, DC: American Psychological Association.

Widom, C. S., \& Maxfield, M. G. (2001). An update on the "cycle of violence". Washington, DC: US Department of Justice, Office of Justice Programs, National Institute of Justice, 184-894.

Wiklund, L. (2008a). Existential aspects of living with addiction - Part I: Meeting challenges. Journal of Clinical Nursing, 17, 2426-2434.

Wiklund, L. (2008b). Existential aspects of living with addiction - Part II: Caring needs. A hermeneutic expansion of qualitative findings. Journal of Clinical Nursing, 17, 2435-2443.

Williams, K. D. (2001). Ostracism: The power of silence. Emotions and social behavior. New York, London: Guilford.

Williams, K. D., Cheung, C. K. T., \& Choi, W. (2000). Cyberostracism: Effects of being ignored over the internet. Journal of Personality and Social Psychology, 79(5), 748-762.

Williams, K. D. (2007). Ostracism. Annual Review of Psychology, 58, 425-452.

Wilson, J. P. (2005). The posttraumatic self: Restoring meaning and wholeness to personality. New York: Brunner Routledge.

Wilson, J. P., Droždek, B., \& Turkovic, S. (2006). Posttraumatic shame and guilt. Trauma, Violence \& Abuse, $7(2), 122-141$.

Wilson, J. Q., \& Herrnstein, R. J. (1985). Crime and human nature. New York: Touchstone Book. Wright,M. O., Crawford, E., \& Sebastian, K. (2007). Positive resolution of childhood sexual abuse experiences: The role of coping, benefit finding and meaning-making. Journal of Family Violence, 22, 597608.

Yalom, I. D. (1980). Existential psychotherapy. NY: Basic Books.

Yoder, C. (2005). The little book of trauma healing: When violence strikes and community security is threatened. Intercourse, PA: Good Books.

Youngs, D., \& Canter, D. (2011). Narrative roles in criminal action: An integrative framework for differentiating offenders. Legal and Criminological Psychology, 17, 233-249.

Youngs, D., \& Canter, D. (2012). Offenders' crime narratives as revealed by the Narrative Roles Questionnaire (NRQ). International Journal of Offender Therapy and Comparative Criminology, 1-23. 
Youngs, D., \& Canter, D. (2013). 'Offenders' crime narratives as revealed by the narrative roles questionnaire. International Journal of Offender Therapy and Comparative Criminology, 57(3), 289-311. Zepinic, V. (2012). The self and complex trauma. United States of America: Xlibris Corporation. Zimbardo, P. G. (1999). Discontinuity theory: Cognitive and social searches for rationality and normalityMay lead to madness. Advances in Experimental Social Psychology, 31, 345-486. 